\title{
Acacias in the New Mexico Desert
}

\section{This attractive, drought tolerant shrub offers food and habitat for wildlife, and even has medicinal uses for humans.}

\author{
By Muhammad Ishaque, Reldon Beck, and Rex Pieper
}

$\Delta$ cacias, shrubs not well understood, contribute to the desert landscape in southern New Mexico by adding habitat and food for animals as well as aesthetics to those who travel these rangelands. Acacias have long been part of the arid and semiarid regions of the world and were recognized by early Native Americans as having curative and medicinal values.

The genus Acacia is from an old word meaning hard or sharp-pointed. This is a genus of 700 to 1200 species, depending upon the taxonomic authority. These species are dispersed throughout the tropics and to some extent into the temperate regions. The largest number of species, more than 300 , are found in Australia. There are 46 species in North America. Many species are spiny, spreading shrubs or small trees with delicate, bipinnate leaves.

As a result of livestock introductions in the past centuries, the acacia populations have expanded. This expansion has not been as rapid or noticeable as that of creosotebush and mesquite in southern New Mexico, but once established the acacias appear to effectively compete with other shrub species.

Following is a general description of viscid acacia and whitethorn acacia-leguminous, native shrubs, which add to the beauty, diversity, and are important for wildlife in the Chihuahuan Desert. Stands of these two species were studied near Las Cruces, New Mexico in 1993 and in 1994, a drought year ( 3 inches of precipitation fell from March through September, $49 \%$ of average). Average annual rainfall for the area is 8.5 inches.

\section{Adaptations To Arid Environment}

Viscid acacia and whitethorn acacia are drought resistant shrubs found in arid areas of southern New Mexico. They can be found growing either as individuals $(<1 /$ acre) among other shrubs (Figure 1) and the many grasses and forbs in the desert, or sometimes in dense, nearly impenetrable stands ( $>1000 /$ acre $)$ on ridge tops or along arroyos (Figure 2.) Both species are cold and drought deciduous. The plants are tough and durable and can tolerate a wide range of unfavorable conditions, including heat and cold, drought, low fertility, stony and alkaline soils.
Both viscid acacia and whitethorn acacia have a deciduous growth pattern. Start of leaf growth after winter dormancy depends on timing of spring and summer rains. In some years when there is little spring rain, growth is not initiated until late June or July when the summer rains start. In other years of more normal rainfall in southern New Mexico, growth will initiate sometime in May, often weeks after mesquite starts growing. During severe droughts the acacia plants may not produce any leaves or flowers in the growing season.

Both species have an asymmetrical growth pattern in the crown. This results from the new shoot tip paling or

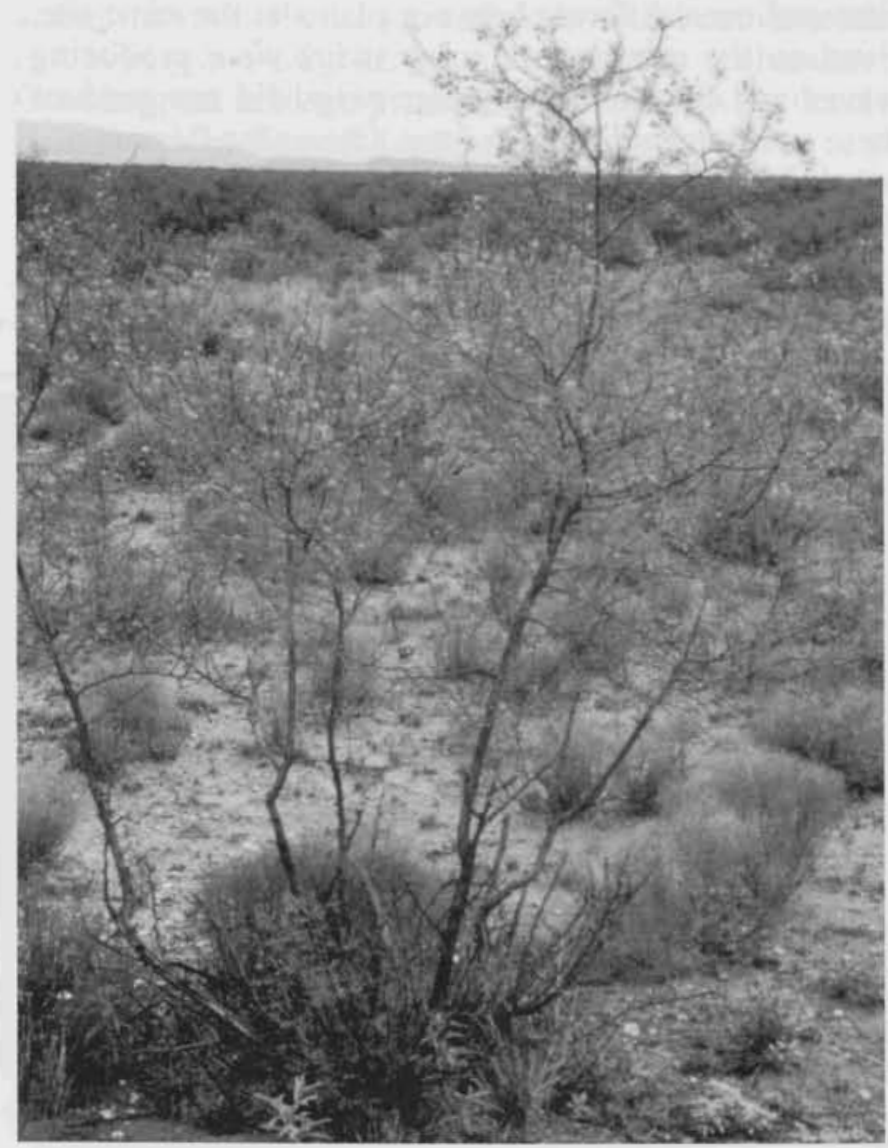

Figure 1. A single whitethorn acacia with flowers on a site in the Jornada Basin dominated by mesquite and snakeweed. 


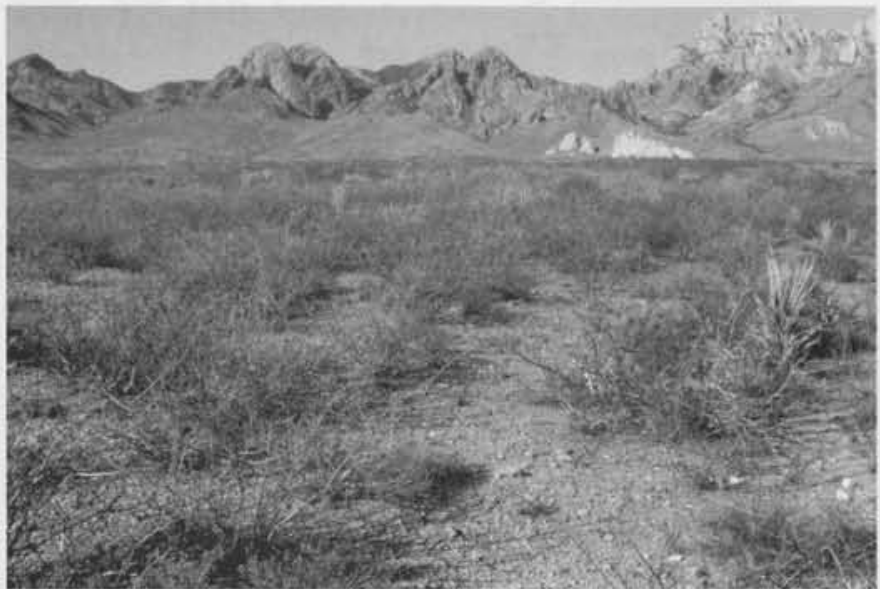

Figure 2. Stand of viscid acacia growing on desert pavement below the Organ Mountains near Las Cruces, New Mexico. Note that very few other species are present in this harsh environment.

yellowing and falling off and new growth for the next year coming from auxiliary buds. Some researchers suggest that this is a mechanism shrubs utilze to reduce evaporation surface under arid conditions.

In 1993 and 1994, the time when leaf and flower growth started was different between years and between sites and even different between plants at the same site. Even on the same plant, some twigs were producing leaves and flowers while other twigs did not produce these structures until much later. Generally, flowers and leaves appear on a branch at the same time (Figure 3). At the end of the reproductive season, pod ripening also varies by several days between plants. Even on the same plant and sometimes on the same branch ripened pods as well as green immature pod were observed.

\section{Acacias Are Attractive}

Viscid acacia is an open, upright shrub (Table 1, Figure 4). The branches of the plants are usually armed with paired white spines. The skeletal, open growth habit and sparse foliage provide an untamed appearance. The leaflets are small, dense, oily green in appearance. The entire plant, including the leaves, stems and pods, are sticky from glandular secretions which appear to give it a distinct odor which is most noticeable soon after a rainfall.

Fragrant yellow clusters of flowers in a ball are sprinkled throughout the shrub from April to July. In a few cases mature pods attained lengths of 3 inches with a maximum of 10 seeds per pod. The ripened pods burst open and seed fell onto the ground around the plant. This type of seed dispersal suggests that for obtaining an accurate estimate of seed production of these species, observations of mature pods should be carried out on a daily basis during pod production.

Whitethorn acacia is an upright or spreading shrub or small tree (Table1, Figure 1). Bark of new twigs is smooth, becoming fissured and gray on older limbs and the trunk. The twigs are often armed with paired white spines. Occasionally some limbs of the plant are spineless or often an entire plant may be spineless.

Yellow-orange, fragrant balls comprised of many flowers dot the foliage. Pods are reddish-brown, curved, about

Table 1. Names, range, habitat and morphological characters of viscid and whitethorn acacias

\begin{tabular}{|c|c|c|c|c|c|}
\hline$\overline{\text { Name }}$ & Scientific Name & \multicolumn{2}{|c|}{ Other Common Names } & Range & Habitat \\
\hline Viscid Acacia & Acacia neovernicosa Isley* & \multicolumn{2}{|c|}{$\begin{array}{l}\text { stickyleaf whitethorn } \\
\text { Chihuahuan whitethorn }\end{array}$} & $\begin{array}{l}\text { Texas to Arizona } \\
\text { south into Mexico }\end{array}$ & $\begin{array}{l}\text { Gravelly, limestone } \\
\text { hills, } 2,800-5000 \mathrm{ft} \text {. } \\
\text { elevation }\end{array}$ \\
\hline Growth Form & New Bark Color & Leaves & Flowers & Pods & Spines \\
\hline $\begin{array}{l}\text { Open, upright, } \\
\text { 3-7 ft. tall, } \\
\text { Canopy 3-10 ft. }\end{array}$ & $\begin{array}{l}\text { Pink to } \\
\text { reddish }\end{array}$ & $\begin{array}{l}\text { leaf divisions } \\
1-2 \text { pairs, glandular, } \\
\text { deciduous, small } \\
\text { dense }\end{array}$ & $\begin{array}{l}\text { Fragrant, yellow, } \\
\text { many in } 0.5 \text { in. glob } \\
\text { April to July }\end{array}$ & $\begin{array}{l}\text { medium brown, } \\
\text { obes, } 1.5-3 \mathrm{in} \text {. long }\end{array}$ & $\begin{array}{l}\text { paired, pinlike, } \\
\text { white spines, } \\
0.5 \text { in., abundant }\end{array}$ \\
\hline Name & Scientific Name & \multicolumn{2}{|c|}{ Other Common Names } & Range & Habitat \\
\hline Whitethorn Acacia & Acacia constricta Gray* & \multirow[t]{2}{*}{$\begin{array}{l}\text { mescat acacia } \\
\text { fragrant acacia }\end{array}$} & & $\begin{array}{l}\text { Texas to Arizona, } \\
\text { northern Mexico }\end{array}$ & $\begin{array}{l}\text { Washes and gravelly } \\
\text { slopes. } 2500-5000 \mathrm{ft} \text {. } \\
\text { elevation }\end{array}$ \\
\hline Growth Form & New Bark Color & & Flowers & Pods & Spines \\
\hline $\begin{array}{l}\text { Often tree-like, } \\
3-10 \mathrm{ft} \text {. tall, canopy } \\
\text { spread of } 3-6 \mathrm{ft} \text {. } \\
\text { more open }\end{array}$ & $\begin{array}{l}\text { Purple gray to } \\
\text { reddish }\end{array}$ & $\begin{array}{l}\text { Leaf division } \\
\text { of } 4-7 \text { pairs, } \\
\text { not glandular, } \\
\text { deciduous }\end{array}$ & $\begin{array}{l}\text { Fragrant, many in } \\
\text { yellow-orange } \\
\text { globes, } 0.5 \text { in. } \\
\text { diam. April to July, } \\
\text { \& late summer in } \\
\text { some years }\end{array}$ & $\begin{array}{l}\text { Reddish brown } \\
\text { curved, } 2-4 \text { in., }\end{array}$ & $\begin{array}{l}\text { paired, pinlike, } \\
\text { white spines, } \\
>0.5 \text { in. Some plants } \\
\text { do not have any }\end{array}$ \\
\hline
\end{tabular}

*Allred 2000. 


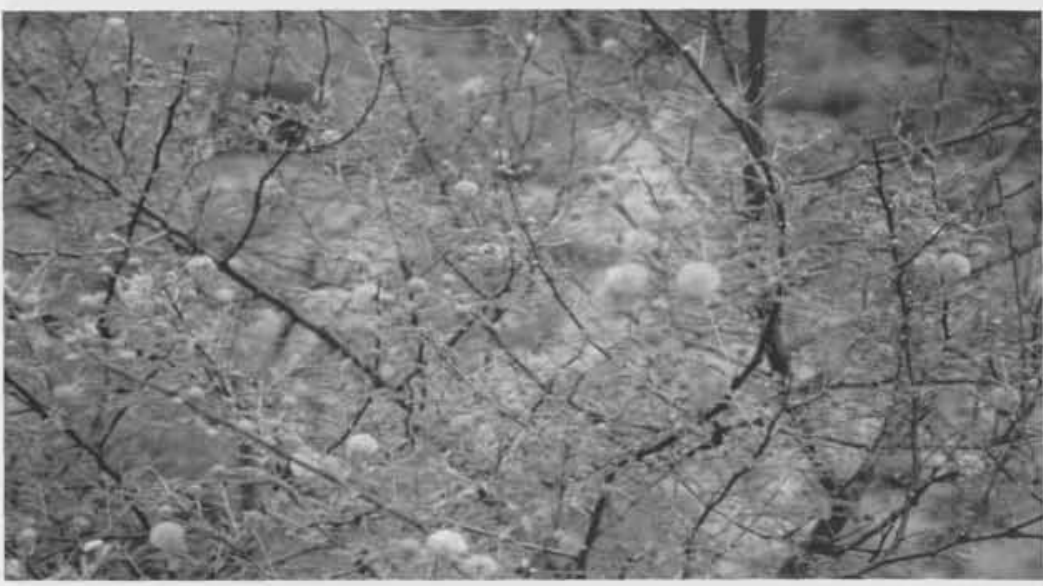

Figure 3. Whitethorn acacia typically flowers shortly after leaves first appear when the late spring/summer rains start. This particular shrub does not have any spines which is not uncommon in this species.

4 inches long and deeply constricted between the seeds. This is the characteristic that gives this acacia its species name. This species blooms between April to June, and again in late summer to mid-fall. Floral buds may appear as late as November-December, but generally temperatures are too cold to permit flower development.

Flowering in this plant is triggered by a rain of at least 0.4 inches, followed by many days with temperatures above 59 F. Only a few of the flowers in each inflorescence produce fruit. The rest which eventually fall are not wasted as they contribute to the showy display that attracts pollinators. Scientists have reported that whitethorn acacia seeds are mature when air temperatures exceed $99 \mathrm{~F}$.

\section{Seeds Need To Be Scarified}

The hard pericarp which surrounds the endosperm in the seeds of these shrubs needs scarification to insure germination. In an Arizona study where germination of whitethorn acacia seeds were tested in a greenhouse, it was found that seedlings emergence was greatest from seeds sown at 0.4 to 0.8 inches depths in sandy loam soils. The optimum germination temperatures for whitethorn ranged from 79 to $88 \mathrm{~F}$ which resulted in seed germination by the $5^{\text {th }}$ day. Germination of scarified seeds exceeded $90 \%$ of those tested.

In a New Mexico trial, germination of non scarified seeds in Petri dishes was less than $11 \%$ and more than $40 \%$ for scarified seeds for both species. When scarified seeds were put into a sandy-loam desert soil, germination exceeded $50 \%$.

Once established, water requirement varies from low to moderate. However, both species grow better in areas where rainwater periodically percolates deep into the soil, especially in areas with less than 10 inches total annual rainfall.

\section{Many Animals Rely On Acacia}

Acacias provide cover and food for many wildlife species. The browse and fruit of the acacias are rich sources of digestible protein for many herbivores. When analyzed in 1993 and 1994, whitethorn acacia had somewhat higher crude protein than the viscid acacia. Crude protein in the whitethorn acacia leaves was nearly $25 \%$ in mid summer while that of the viscid acacia was about $16 \%$. Leaves for both species had $3-7 \%$ less crude protein at the end of the growing season than during the growing period. The green pods had nearly the same percentage crude protein as the green leaves in the respective species. Crude protein declined as the pods matured, but the mature pods still provide an important food source for many animals.

Some of the dead branches found on both the viscid and whitethorn acacia plants resulted from black-tailed jackrabbits eating the bark on the stems just above ground level. This bark is an important food-item for the jackrabbits, especially when other forage plants are scarce during drought. The bark may also be used by cotton-tail rabbits and some rodent species. Deer occasionally browse the leaves and pods. Quail eat its seeds extensively in areas where this plant species is abundant. Grasshoppers used the plant leaves, while ants ate developing seeds in the pods on the plants.

Seed beetles or bean weevils sometimes laid eggs in the pods and seed which lead to consumption of the inner parts of the seeds. These beetles (personal communication, Dr. David Richman, New Mexico State

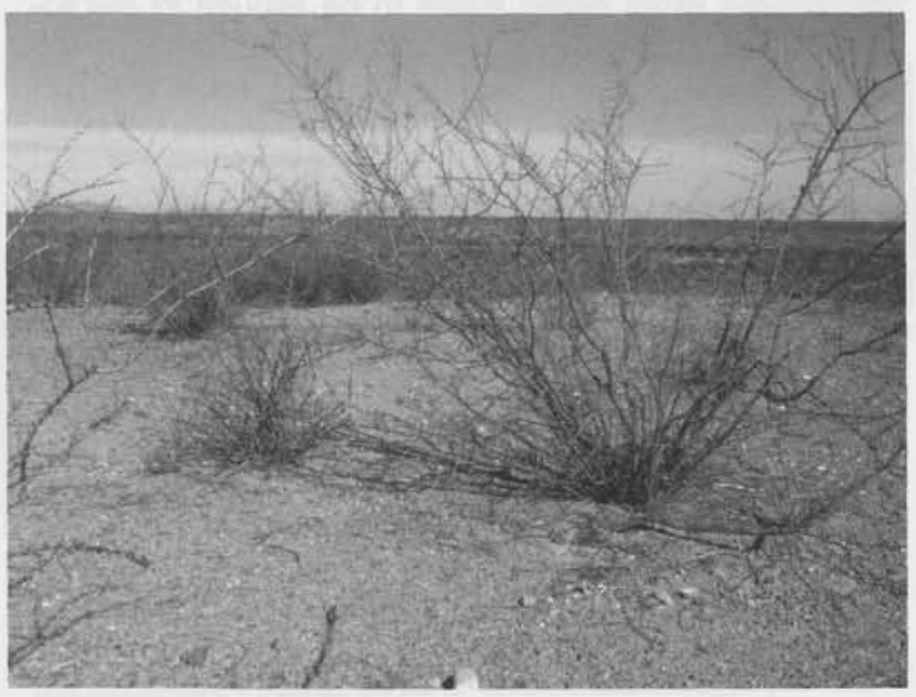

Figure 4. Two viscid acacia plants in spring before green-up. Due to unfavorable growing conditions on some ridgetops, the shrubs are widely spaced and only a few herbs grow here after the rains start. 
University) emerge from the stored seeds by making a hole before the start of the growing season. Caterpillars may defoliate its leaves in the spring, but new leaves develop quickly. These plants are favored by bees for making honey in the southern Trans Pecos of southern New Mexico and west Texas.

\section{Management \& Control}

Both acacia species are high in cyanide forming compounds, but only a few clinical problems have been reported even though they are used for forage during drought conditions. Some death losses of livestock have been reported by animals eating acacia in most parts of their ranges. In summer the plants are rarely eaten by cattle although the pods are browsed sometimes. However, in the fall of the year when frosts occur and range grasses become less palatable, cattle may eat a considerable amount of these plants and death may result. The leaves of the plants may have high $\mathrm{HCN}$ content and the plant may retain their high $\mathrm{HCN}$ content for considerable time in the dry state.

In rangelands where either whitethorn or viscid acacia have relatively dense stands and herbaceous forage is limited, it may be important to control livestock access to those ranges. The most critical time appears to be in the early frost period in the fall. To avoid poisoning it may be necessary to remove all livestock and put them on ranges that are not infested with acacia.

On some ranges the acacias become so dense that they limit the movement of livestock and the people trying to herd the animals. On fertile soil areas, shrub control treatments may be desirable. Successful herbicide applications include treating individual plants by putting the herbicide around the base of the plant, or by large scale applications using either liquid to be applied to the foliage or dry herbicides to be incorporated through the roots. Tebuthiuron is a soil applied herbicide that has been successfully used (personal communication, Dr. Kirk McDaniel, New Mexico State University). Large scale treatments may not be practical or economical on areas of shallow soils or where there is little chance for herbaceous plants to become established.

About the authors: Ishaque is Lecturer, Department of Forestry, Range Management and Wildlife, University of Agriculture, Faisalbad, Pakistan (current address: 1358 Duffererin Place, Windsor, Ontario, N8X $3 K I$ Canada), Beck, and Pieper are Professor and Professor Emeritus, respectively, Animal and Range Sciences Department, New Mexico State University, Box 30003, Las Cruces, NM 88003.

\section{References and Other Readings}

Allred, K. W. 1991. An annotated checklist of poisonous or injurious plants of New Mexico. New Mexico State Univ. Coop. Ext. Serv. 400 B-14, Las Cruces, N. M.

\section{Acacias offer medicinal and landscape uses as well}

Acacias can be used as background shrubs and are well suited for desert landscapes. They may be used in a garden where the flowers can perfume the air. They have been used for transitional or natural gardens, and also as barrier plants along arroyos banks. They've proven useful in preventing animals from grazing the area and causing erosion. They are also used for replanting disturbed desert areas or for increasing plant diversity in sparse desert areas.

The species has also been reported to be used for medicinal purposes for both humans and livestock. The leaves and pods when ground into a powder make an excellent infused tea for diarrhea and dysentery, as well as strongly astringent haemostatic and antimicrobial wash. The straight powder is widely used by Native Americans for treating sore backs and flanks of their horses. Tea made from the flowers and leaves acts as a sedative and is a good inflammatory for stomach and esophageal nauseas, vomiting, and hangovers. The pods of the plant are used for conjunctivitis. The root is thick and mucilaginous as a tea and is good for sore throats and mouth inflammations as well as dry, raspy coughing.

Allred, K. W. 2000. A field guide to the flora of the Jornada Plain. 3rd ed. New Mexico State Univ. Range Science Herbarium. Las Cruces, N. M.

Bowers, J. E. 1993. Shrubs and trees of the southwest deserts. Southwest Parks and Monuments Assoc. Tucson, Ariz.

Burrows, George E. and Ronald J. Tyrl. 2001. Toxic plants in North America. Iowa State Univ. Press, Ames, Iowa.

Cox, J. R., A. De Alba-Avila, Q. R. Richard and J. N. Cox. 1993. Biological and physical factors influencing Acacia constricta and Prosopis velutina establishment in the Sonoran desert. J. Range Manage. 46:43-48.

Ishaque, Muhammad, 1996. Ecology of Acacia species in Chihuahuan Desert Rangeland. Ph. D. Dissertation. New Mexico State University, Las Cruces, N. M.

Isley, D. 1969. Legumes of the Unites States: 1. Native Acacia. In: Sida Contributions in Botany. 3:365-386.

Johnson, M. B. 1993. Woody legumes in southwest desert landscapes. Desert Plants 10:143-170.

Moore, M. 1989. Medicinal plants of desert and canyon west. Museum of New Mexico Press. Santa Fe, N. M.

Nokes, J. 1986. How to grow native plants of Texas and the Southwest. Texas Monthly Press. Austin, Tex.

Powell, A. M. 1988. Trees and Shrubs of Trans-Pecos Texas, Sul Ross State Univ. Alpine, Tex. 